\title{
REQUIREMENTS FOR CHARAC'TERIZATION OF DWPF CANISTER WELDS AND LABELS, AND ESTIMATES OF SERVICE LIFE (U)
}

by M. J. Plodinec

WSRC-RP- $-93-105$

Westinghouse Savannah River Company

DE93 009901

Savannah River Site

Aiken, South Carolina 29808

Other Authors:

J. R. Harbour

(WSRC)

S. L. Marra

(WSRC)

This paper was prepared in connection with work done under Contract No. DE-AC09-89SR18035 with the U. S. Department of Energy. By acceptance of this paper, the publisher and/or recipient acknowledges the U.S. Government's right to retain a nonexclusive, royalty-free license in and to any copyright covering this paper, along with the right to reproduce and to authorize others to reproduce all or part of the copyrighted paper.

\section{MASTER}

UISTIRIBUTION OF THIS DOCUMENT IS UNLIMITED 


\section{DISCLAIMER}

This report was prepared as an account of work sponsored by an agency of the United States Government. Neither the United States Government nor any agency thereof, nor any of their employees, makes any warranty, express or implied, or assumes any legal liability or responsibility for the accuracy, completeness, or usefulness of any information, apparatus, product, or process disclosed, or represents that its use would not infringe privately owned rights. Reference herein to any specific commercial product, process, or service by trade name, trademark, manufacturer, or otherwise does not necessarily constitute or imply its endorsement, recommendation, or favoring by the United States Government or any agency thereof. The views and opinions of authors expressed herein do not necessarily state or reflect those of the United States Government or any agency thereof.

This report has been reproduced directly from the best available copy.

Available to DOE and DOE contractors from the Office of Scientific and Technical Information, P.O. Box 62, Oak Ridge, TN 37831; prices available from (615) 576-8401, FTS 626-8401.

Available to the public from the National Technical Information Service, U.S. Department of Commerce, 5285 Port Royal Rd., Springfield, VA 22161. 
Tก:

ก. T. RANKTN

EROM:

M. J. PLODINEC, J. R. HARBOUR, S. L. MARRA

\section{RTOOIRTMIMNTS FOR

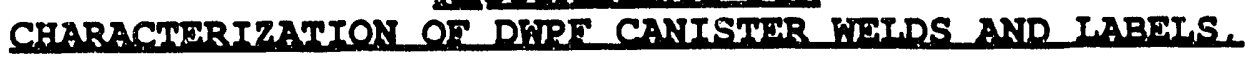 AND FSTTMATHS OF SMRVTCT LIIDS}

\section{INTERODUCTION AND SUMYARY}

The Department of Energy has established specifications for the DWPE product, I which require that the DWPE

- Provide estimates of the service life of the canister label,

- Provide assurance that the DWPE canister will be leaktight when shipped,

- Demonstrate that the contents of the canistered waste form will not lead to internal corrosion of the canister.

The DWPF has elected to meet these requirements, in part, by characterizing canisters produced in the facility during the Startup Test Program. This includes canisters filled on the pour turntable (normal conditions) and canisters filled on the drain turntable (credible upset conditions expected to be more severe due to higher temperatures). This document identifies the requirements for characterization of the canister fabrication welds and canister labels (characterization of canister closure welds is being performed by Equipment Engineering Section), and for estimation of their service life in DWPE's Glass Waste Storage Building. John $R$. Harbour will act as Glass Technology's Technical Liaison for this activity.

\section{BACKGROUND}

Specification 2.3, "Identification and Labeling," requires that the DWPE estimate the service life of the label while the canisters are in DWPE's custody.1 The canister label is Type 308 stainless steel filler metal welded to the canister surface. In the Waste Form Compliance Plan, 2 the DWPF lays out a strategy for compliance with this specification. This strategy is based on showing that the label would have approximately the same life as the Type 308 stainless steel used to weld the canister together. Rough estimates are that this could be as long as several thousand years.

Specification 2.2 requires that the DWPF provide assurance that the sealed canister would maintain leaktightness while the canisters are in DWPE's custody.1 
Specification 3.9 requires that the contents of the canistered waste form not lead to significant internal corrosion of the canister. In this context, "significant" means that there would be an adverse impact on either normal handling or resistance to accident conditions, such as a drop of the canistered waste form.

These specifications, taken together, lead the DWPF to characterize both the welds and the label, and to estimate their longevity under the conditions expected during interim storage in the DWPE's Glass Waste Storage Building.

Thus, the objectives of the study are to:

- Characterize beth canister welds and canister labels. The canisters to be sampled will have seen either expected or credible upset (i.e. canister filled through melter drain) process conditions. The characterization will include determination of the degree of sensitization and the formation of embrittling phases within the welds and labels, the effects of heating due to canister filling, and microstructural examination of the bonded and heat-affected areas. Samples will be taken from canisters from each of three vendors, and at several locations (especially those expected to see the highest temperatures).

- corrosion testing of weld samples. The anticipated maximum surface temperature in the GWSB is approximately $100^{\circ} \mathrm{C}$. The halide-rich environment inside the canister has the potential to lead to corrosion over the nearly half-century of storage at SRS. Previous work by Langton ${ }^{3}$ has demonstrated that localized corrosion will not be a problem within the canister. Confirmatory testing under the Quality Assurance Requirements Document, RW-0214, is required to qualify this data. In addition, Langton's work should be extended up to the maximum anticipated surface temperature $\left(\sim 100^{\circ} \mathrm{C}\right)$. Samples will be provided from canisters from each of three vendors, so that a comparison of the vendors can be made.

- Estimation of the service life of the 308 metal in the Glass Waste storage Building (GWSB). This objective will use the results from the two previous objectives. Estimation of both external corrosion (due to the atmosphere in the GWSB) and internal corrosion (due to the halide-rich environment inside the canister) is required. The degree of conservatism associated with these estimates is also required.

\section{BBOOTR MVITANTS}

The requirements for this task are as follows:

- A task plan must be prepared, which conforms to the requirements of GT-QA-2-5 (attached). This task plan will describe the technical program to be carried out; and should identify the following: 
- Ine cask ieader.

- Sample requirements: the tipe, number, location, and any special handling requirements should be identified. J. R. Harbour will be responsible for ensuring that samples are provided which meet your requirements.

- Method(s) to be used to characterize samples from canisters.

- Method of approach for making estimate of service life, including testing and analysis techniques.

- Erequency of interim reports.

- Estimates of cost, manpower, and schedule.

The task plan will identify the key elements which must be controlled to ensure the success of the effort. This task plan must be approved by M.J. Plodinec, E. W. Holtzscheiter, and the Manager, Process Engineering before the work begins.

- As indicated in GT-QA-2-5, a quality assurance plan for the task must also be prepared, which will identify how the key elements in the task plan will be controlled. This plan must be approved by M.J. Plodinec and E. W. Holtzscheiter, and by SRTC's Quality. Section. The task QA plan nay be appended to the task plan.

- A technical review of test methods and results will be perfomred at the conclusion of testing. The technical review team will be headed by Glass Technology's Technical Liason, who will name other team member. A technical report summarizing the results of the investigation will be prepared, and issued after the technical review. A copy of this report, and interim progress reports, will be included in the records package (see below) for the effort.

- A records package will be developed for this effort, which conforms to GT-QA-17-2 (A copy of GT-QA-17-2 has been sent to you.). This records package will be sufficiently complete so that the work could be independently reconstructed, if necessary. This package shall contain records identified in the task plan, and shall include the following:

- Authenticated copies of this document, and of the task plan.

- Authenticated copies of qualification records for all participants in the work.

- Original documents, or authenticated copies, of procedures or instructions actually used during the investigation, which would be necessary to reproduce the re- 
sults of the eirort.

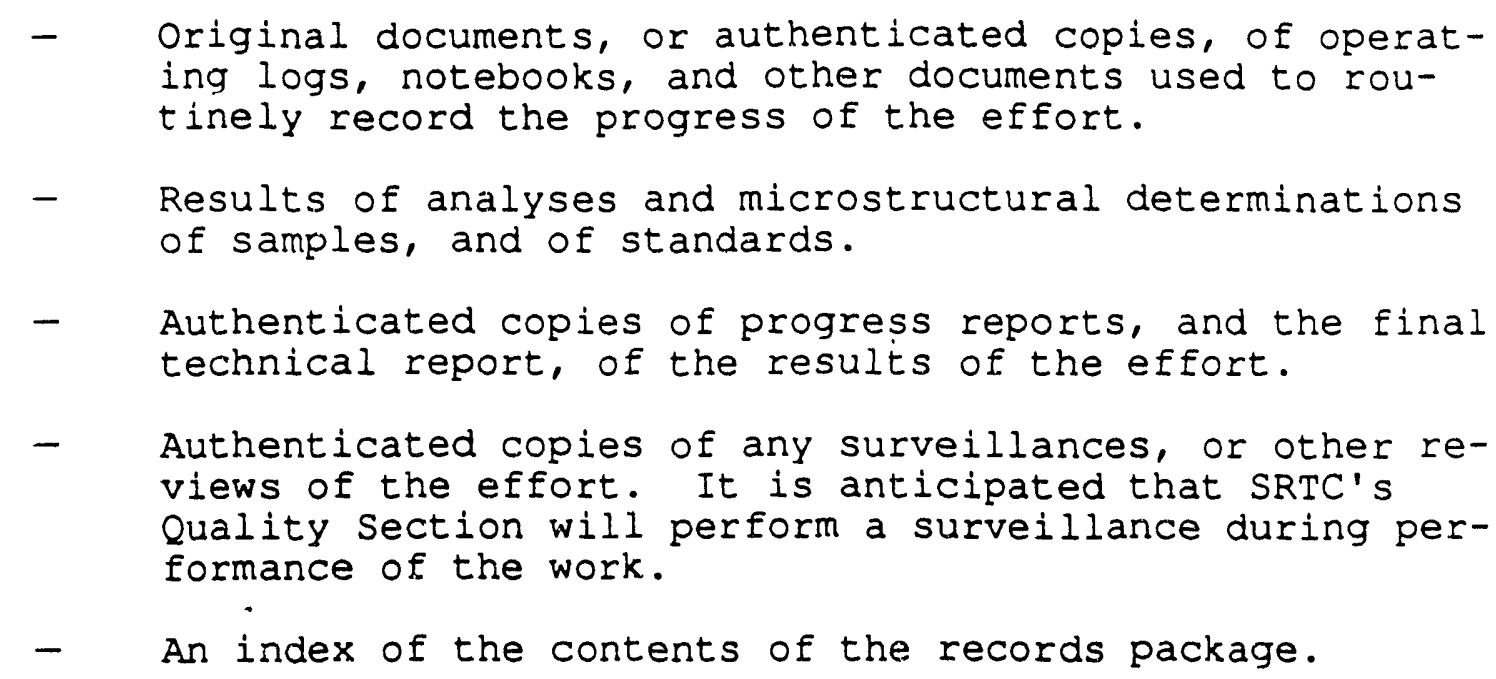

- At the conclusion of the ejfort, the records package will be transmitted to K. E. Mottel, 773-43A, to initiate review of the records package for completeness. Once the results are accepted, the records package will be transmitted, by her, to SRS' records management facilities for storage.

\section{DFTINVARABTHS}

The following are the deliverables for this effort:

- The approved task plan, and QA plan.

- Interim progress reports (preferably provided on a quarterly basis), and the final technical report.

- The records pàckage for this effort.

\section{BMTHRTNCTS}

1. Office of Civilian Radioactive Waste Management, Waste Acceptance Preliminary Specifications for Vitrified High-Lovel Waste Forms, Draft for approval, June, 1991.

2. S. L. Marra, M. J. Plodinec, DWPI Waste Form Compliance Plan, WSRC-IM-91-116-0, Revision 0, Westinghouse Savannah River Co., Aiken, SC 29802 (1992).

3. C. A. Langton, "DWPF Canister Corrosion Experiments," DPST-83-749, September, 1983. 
January 11, 1993

5

WSRC-RP-93-105

APPROEALS
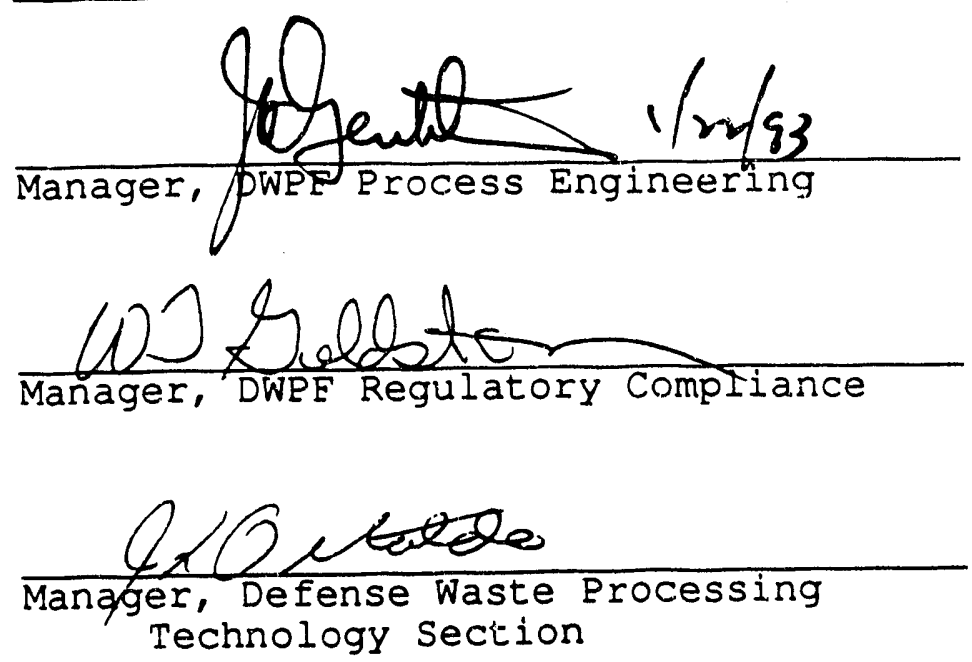

Ed Holtzachiter 

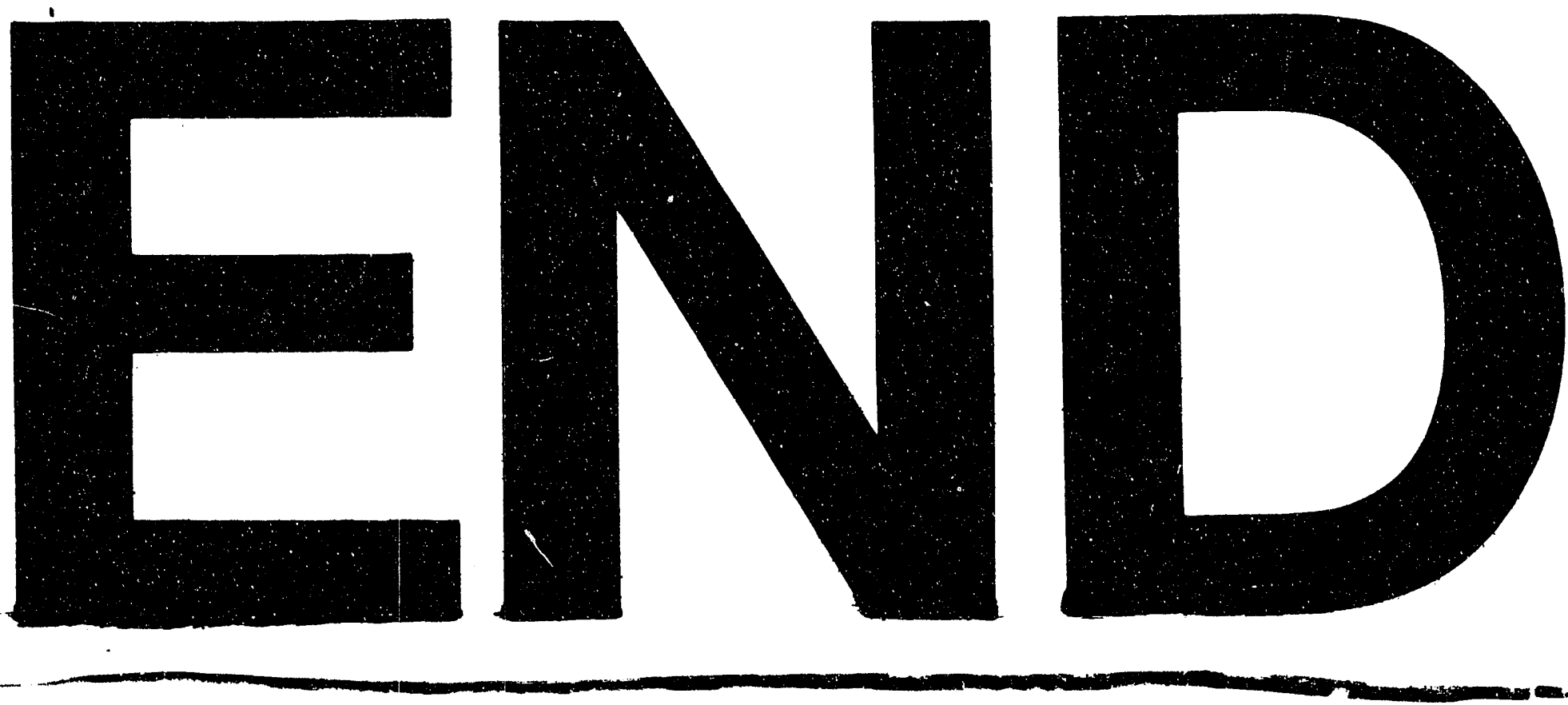
